\section{Pan Indian Ocean Science Association : Congress in Perth, Western Australia}

Tre second science congress of the Pan Indian Ocean Science Association will be held in Perth in the University of Western Australia during August 17-24, under the presidency of Prof. H. J. Bhabha. The Association, which was formed in January 1951 at a meeting in Bangalore, exists to discuss and promote concerted action in regard to scientific problems affecting the peoples and countries around the Indian Ocean and generally to improve friendship and co-operation among them. Representatives are sent from Australia, Burma, Ceylon, France, India, Madagasear, Malaya, Netherlands and Portugal. Those attending the congress will be in one of three categories: official delegates of each participating country, the limit being ten per country; accredited members, who are nominated by the representative institution of the member country; and guests invited by the president. The work of the congress will be for the most part arranged by the seven sections of the Association: $(A)$ physical sciences; $(B)$ biological sciences; $(C)$ geological sciences; (D) agricultural sciences ; $(E)$, economios, education and social sciences; $\left(F^{\prime}\right)$ geography and oceanography; and $(G)$ human ecology. During August 25-28 a number of excursions will be made, catering mainly for those concerned with the bio. logical sciences; geology and mining; and agricultural sciences and forestry. All communications relating to the congress should be addressed to Prof A. D. Ross, Honorary Secretary, P.I.O.S.A., 31 Ventnor Avenue, West Perth, Western Australia.

\section{Vacuum Techniques: Symposium in the United States}

A sYMPosium on high vacua, organized by the Committee on Vacuum Techniques, will be held at the Berkeley Cartaret Hotel, Asbury Park, New Jersey, during June 16-18, 1954. The papers to be read will deal with the following five topics : a panel on nomenclature and standards; new equipment and instruments; fundamental developments in vacuum technology; methods and techniques; and applications and processes. The Committee on Vacuum Techniques has been organized as a non-profit corporation, with the prime purpose of sponsoring the symposium; in addition, it hopes to further the dissemination of knowledge of high vacuum techniques and to assist in the establishment of universally acceptable nomenclature and standards. All individuals and companies interested in attending the symposium, presenting papers or participating in other activities of the Committee should write to the Committee at P.O. Box 1282, Boston, Mass.

\section{Chemical Society: Officers}

Officers of the Chemical Society have been elected as follows : President, Prof. W. Wardlaw; Vice-Presidents, Sir Ian Heilbron, Sir Cyril Hinshelwood, Prof. C. K. Ingold, Dr. W. H. Mills, Sir Eric Rideal, Sir Robert Robinson, Prof. R. D. Haworth, Prof. E. L. Hirst, Prof. E. R. H. Jones, Prof. R. P. Linstead, Prof. W. H. Melville and Sir John Simonsen ; Treasurer, Mr. M. W. Perrin ; Secretaries, Prof. H. Burton, Prof. E. D. Hughes and Dr. L. E. Sutton; New Members of Council, Dr. C. C. Addison, Dr. V. C. Barry, Dr. E. J. Bourne, Dr. E. A. Braude, Dr. H. M. N. H. Irving, Prof. J. M. Robertson, Prof. H. N. Rydon and Prof. H. D. Springall.

\section{Announcements}

Prof. T. H. MarshatL, professor of social institutions in the London School of Economics and Political Science, has been appointed to the Martin White chair of sociology tenable at that School. The title of reader in education in the University of London has been conferred on Mr. A. C. F. Beales in respect of the post held by him in King's College.

THE bequests recently made to the University of Sheffield under the wills of the late Sir George Franklin, who died in 1916, and Miss Daisy Franklin, who died in 1948, will be used for the endowment of the full-time chair of medicine in the University, which will henceforth be known as the Sir George Franklin chair of medicine. Sir George Franklin was pro-chancellor and chairman of council of the University during 1905-16.

THE second annual meeting of Committee $E-14$ on Mass Spectrometry, of the American Society for Testing Materials, will be held during the week beginning May 24 at the Jung Hotel, New Orleans, Louisiana. Forty-six papers will be presented, covering isotopic abundance determinations, ionizetion potentials, solids analysis, high molecular-weight analysis, and new mass-spectrometer techniques and developments. During the week the election of new officers of the $E-14$ Committee will be made. Further details can be obtained from Mr. William Priestley, jun., Standard Oil Development Co., P.O. Box 121, Linden, New Jersey.

THE annual Cornell University summer laboratory course in techniques and applications of the electron microscope will be given during June 14-26 in the Laboratory of Electron Microscopy, Department of Engineering Physics, under the direction of Dr. Benjamin M. Siegel. The course is designed for research workers in academic institutions or industry who have recently entered the field of electron microscopy or who are now planning to undertake research problems involving applications of this instrument. Inquiries should be addressed to $\mathrm{Dr}$. Siegel at the Department of Engineering Physies, Rockefeller Hall, Cornell University, Ithaca, New York.

THe Textile Institute is offering a Cotton Industry War Memorial Scholarship, of maximum value $£ 950$, for a three-year course in textile technology at an advanced level, with provision for industrial training and experience of a special character in Britain or overseas. The closing date for applications is April 30. The Institute is also offering a Peter Coats Scholarship, of maximum value $£ 200$, for one year of full-time study preparatory to taking up a course in textile technology at a university or college. The closing date for applications is May 31. Candidates for both these awards must be male British nationals less than twenty-four years of age. Application forms and further details can be obtained from the General Secretary, Textile Institute, 10 Blackfriars Street, Manchester 3.

The second general assembly of the Italian Geophysical and Meteorological Society will be held in Genoa during April 23-25. The first two days will be devoted to the reading of twenty-three papers, and the final day will be reserved for the discussion of the Society's affairs and an excursion. Further information can be obtained from the Societd Italiana di Geofisica e Meteorologia, via Balbi 5, Genova. 